\title{
Influence of Auditor Competency in Using Information Technology on the Success of E-audit System Implementation
}

\author{
Taufiq Supriadi ${ }^{1 *}$, S. Mulyani ${ }^{2}$, Eddy Mulyadi Soepardi ${ }^{2}$, Ida Farida ${ }^{2}$ \\ ${ }^{1}$ Student of Doctoral Program of Accounting Science, Faculty of Business and Economics, Padjadjaran University, Dipatiukur \\ Road No. 35 Bandung West Java, INDONESIA \\ ${ }^{2}$ Lecturer of Doctoral Program of Accounting Science, Faculty of Business and Economics, Padjadjaran University, Dipatiukur \\ Road No. 35 Bandung West Java, INDONESIA
}

Received 1 September 2018 - Revised 6 November 2018 - Accepted 3 December 2018

\begin{abstract}
Indonesia has recently witnessed a development in accounting information system with the inrtroduction of computer-assisted mechanism. The Audit Board (BPK) while implementing the e-Audit system, aimed at reducing conflicts between auditors and state bureaucrats. This study is based on the phenomenon that occurred regarding the low quality of the e-audit system in several agencies, like government agencies, and private institutions. The study aims to analyze the extent to which auditor's competencies can help in successful implementation of the e-Audit system. The study used a sample of 380 BPK Auditors through random sampling using a questionnaire. The data was analyzed through statistical descriptive analysis and structural equation modeling techniques. The results provide empirical evidence that Auditor Competence in Using Information Technology has a significant positive influence on the success of the e-Audit System Implementation.
\end{abstract}

Keywords: auditor's competency, use of information technology, e-Audit System, AIS

\section{INTRODUCTION}

The Audit Board of the Republic of Indonesia, hereinafter referred to as BPK, assumes the responsibility of assessing the truth, accuracy, credibility, and reliability of information related to the management and responsibility of the State finances (Law No. 15 of 2004). tate financial experts in both local and central governments. Initiatives have also been taken for the implementation of the Information Computer Technology (ICT)-based accounting information system in all government transactions in order to achieve audit discipline and develop techniques for performing regular computer-assisted audits.

The Audit Board of the Republic of Indonesia (BPK) agreed to implement an e-Audit system or providing online access to State financial management data in the State Budget (APBN). Moermahadi (2017) informs that a memorandum of understanding was signed between two parties allowing BPK to access the accountability data so that the examination can be more effective and efficient through an e-Audit system. The e-Audit system is a system to verify or check accounting transactions including the sources that are processed in an electronic environment, using analysis, evaluation, and testing of audit methods, and assisted by computerized tools. This technique is now appropriate to be used in audit purposes so that the e-Audit system is increasingly integrated into the income audit program (Finnegan, 2011: 75).

The importance of the e-Audit system was also revealed by the Minister of Administrative and Bureaucratic Reform, EE. Mangindaan, as quoted by Kompas on February 9, 2011, that electronic-based checks (e-Audit system) that are immediately carried out by the BPK will reduce the contact between auditors and state financial managers in ministries and institutions. Therefore, the e-Audit system is believed to reduce violations and corruption in the management of the State finances. The direct contact of the examined party and the examining one so far has become an opportunity for increased violations and corruption.

(C) 2019 by the authors; licensee Modestum Ltd., UK. This article is an open access article distributed under the terms and conditions of the Creative Commons Attribution License (http://creativecommons.org/licenses/by/4.0/).

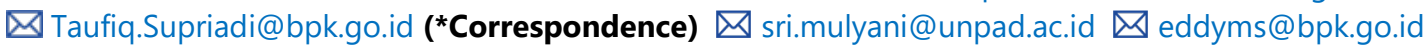




\section{Contribution of this paper to the literature}

- This study proves statistically, that is, the higher the auditor competency the more the success of the e-audit systems implementation.

- Empirically, this research proves the successfull of implementation of e-audit system is influenced by the use of information technology.

- The model in this study can be used to measure the success of e-audit implementation from the perspective of auditor competences and the use of information technology.

Table 1. Corruption Case based on Investigation Phase, Semester I

\begin{tabular}{cccc}
\hline Note & Number of Cases & State Loss Value (in Billion, IDR ) & Bribery Value (in Billion, IDR ) \\
\hline Embezzlement & 70 & 164 & - \\
\hline Fictitious Activities / Projects & 34 & 246.8 & - \\
\hline Budget Abuse & 25 & 96.5 & - \\
\hline Mark Up & 23 & 107 & - \\
\hline Abuse of Authority & 19 & 218.1 & - \\
\hline Mark Down & - & - & - \\
\hline Fictitious reports & 13 & 14.6 & 28.6 \\
\hline Bribery / Gratification & 15 & & - \\
\hline Deduction & 8 & 37.4 & - \\
\hline Extortion & 2 & 0.07 & - \\
\hline Double Budget & - & - & - \\
\hline Illegal Charges & 1 & 0.17 & - \\
\hline Money laundering & 1 & 5.3 & $\mathbf{2 8 . 6}$ \\
\hline Total & $\mathbf{2 1 0}$ & $\mathbf{8 9 0 . 5}$ & \\
\hline
\end{tabular}

Souce: ICW (2016)

Table 2. Corruption acts handled by the KPK based on profession / position

\begin{tabular}{|c|c|c|c|c|c|c|c|c|c|c|c|c|c|c|}
\hline Jabatan & 2004 & 2005 & 2006 & 2007 & 2008 & 2009 & 2010 & 2011 & 2012 & 2013 & 2014 & 2015 & 2016 & Jumlah \\
\hline $\begin{array}{l}\text { Anggota DPR } \\
\text { dan DPRD }\end{array}$ & 0 & o & o & 2 & 7 & 8 & 27 & 5 & 16 & 8 & 9 & 19 & 23 & 124 \\
\hline $\begin{array}{l}\text { Kepala } \\
\text { Lembaga/Kem } \\
\text { enterian }\end{array}$ & 0 & 1 & 1 & o & 1 & 1 & 2 & 0 & 1 & 4 & 9 & 3 & 2 & 25 \\
\hline Duta Besar & 0 & 0 & 0 & 2 & 1 & 0 & 1 & 0 & 0 & 0 & 0 & 0 & 0 & 4 \\
\hline Komisioner & 0 & 3 & 2 & 1 & 1 & 0 & 0 & 0 & 0 & 0 & 0 & 0 & 0 & 7 \\
\hline Gubernur & 1 & 0 & 2 & 1 & 1 & 2 & 1 & 0 & 0 & 2 & 3 & 3 & 1 & 17 \\
\hline $\begin{array}{l}\text { Walikota/Bupa } \\
\text { ti dan Wakil }\end{array}$ & 0 & 0 & 3 & 6 & 6 & 5 & 4 & 3 & 3 & 3 & 12 & 4 & 9 & 58 \\
\hline Eselon I/ II / III & 2 & 9 & 15 & 10 & 22 & 14 & 12 & 15 & 8 & 7 & 2 & 7 & 10 & 133 \\
\hline Hakim & 0 & 0 & 0 & 0 & 0 & 0 & 1 & 2 & 2 & 3 & 2 & 3 & 1 & 14 \\
\hline Swasta & 1 & 4 & 5 & 3 & 12 & 11 & 8 & 10 & 16 & 24 & 16 & 18 & 28 & 156 \\
\hline Lainnya & 0 & 6 & 1 & 2 & 4 & 4 & 9 & 3 & 3 & 8 & 8 & 5 & 25 & 78 \\
\hline $\begin{array}{l}\text { Jumlah } \\
\text { Keseluruhan }\end{array}$ & 4 & 23 & 29 & 27 & 55 & 45 & 65 & 38 & 49 & 59 & 61 & 62 & 99 & 616 \\
\hline
\end{tabular}

Source: KPK 2017

Practices of Corruption, Collusion and Nepotism, inefficiencies in budgets, and ineffectiveness in managing State finances are things that are familiar in everyday life. Such practices are still existing in Indonesia so far and are factors that can disrupt people's welfare (Cahyono \& Siswantoro, 2016: 2). Corruption practices in Indonesia, published by Indonesian Corruption Watch (ICW, 2016) can be seen in Table 1.

The criminal acts handled by the Corruption Eradication Commission (KPK) based on the profession/position in the period of 2004-2016 according to the KPK (2017) are shown in Table 2.

KPK (2017) added that corruption has an impact on reducing State revenues and wasting State finances (see Figure 1). 
Survey Persepsi Masyarakat oleh KPK, Tahun 2010, 6 kota, 2.500 responden)

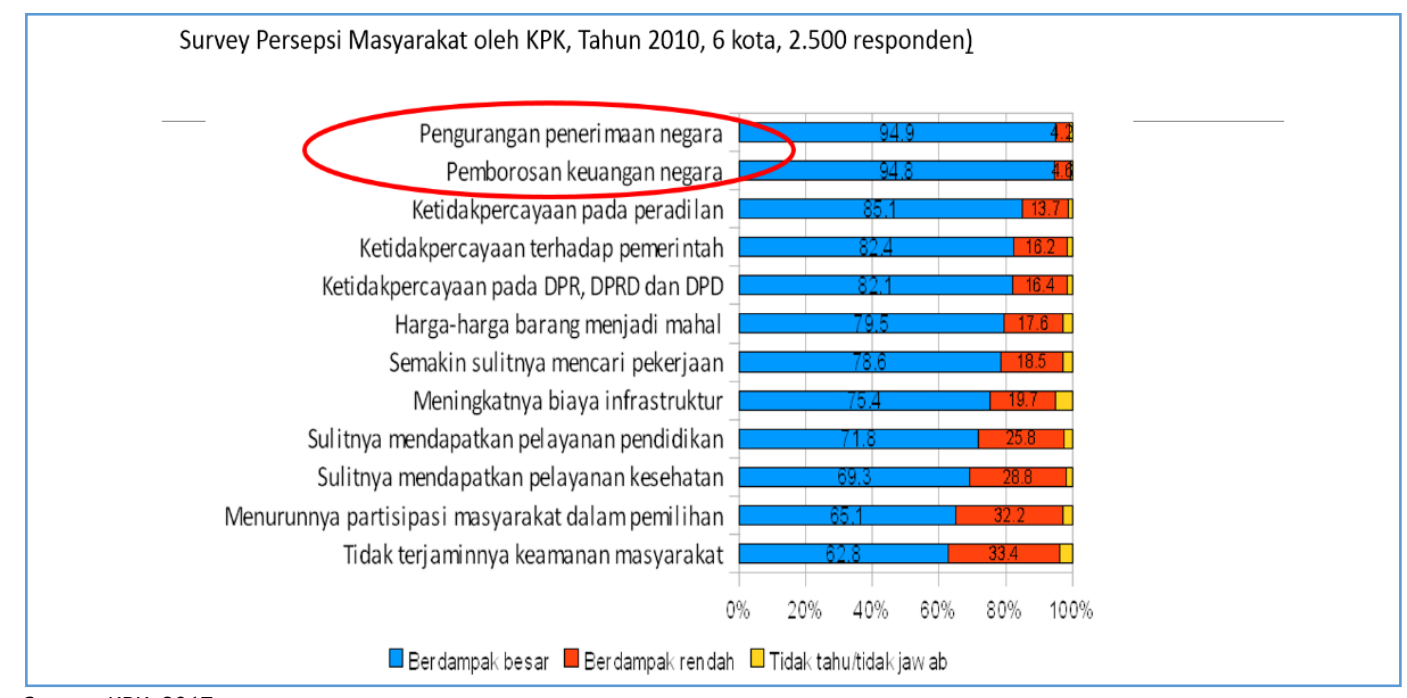

Source: KPK, 2017

Figure 1. Corruption Impact

Cahyono and Siswantoro (2016: 2) in their research stated that one of the causes of corrupt practices is the weak examination in the management of State finances. The weak examination can occur if the audit function on State finances is still weak. For this reason, the role of the Audit Board of the Republic of Indonesia (hereinafter referred to as BPK) in terms of examining the management and responsibility in State finances becomes very important.

Poernomo's opinion above is in line with Praseno's research (2012: 19) that based on the report of the global eAudit system in 2011, there were several findings in the implementation of the e-Audit system that could be classified into two aspects, namely infrastructure support and link-and-match process (BPK, 2011: 27-28):

1) Infrastructure problem. This kind of problems is very important in the development of e-Audit system projects. However, hardware limitations found in representative offices and data transmission requirements between BPK offices hampered the progress. Most auditors used their own computers to conduct audits. This happens because of the limitations of the computer provided by the office, while at the same time not all computers were treated properly. There were also restrictions for desktop computers where only one was available for each sub-department that was connected to the Internet. Other problems occurred due to the poor internet connection (poor access network) and limited media interfaces (command center, e-Audit system portal, helpdesk). Wi-Fi access was not provided, so auditors must wait in a queue to access data from a desktop computer. Otherwise, they must buy their own internet package. Standard Operating Procedure (SOP), especially retrieving, collecting, and distributing data from one entity to another, which was not fully guaranteed to make it vulnerable and open up opportunities for abuse by unwanted people. This is closely related to IT maturity owned by the Auditee.

2) Problems with the link-and-match process. This problem comes from [1] Type of data, where data entered in the data center comes from various different system forms and applications. The findings in the field indicated that this problem must make additional work for database operators who temporarily have to reedit the data and use manual templates. This is all because of the standard software used by the auditee; [2] It takes a long time for data collection because of the ineffective process of integration, transmission, and communication to the entity to identify the data needed. For e-audit system projects, communication for entities is important so that the auditee can identify specific data needed for audit purposes. When achieved, the volume of data integrity, accuracy, and activity can be reduced. However, according to documented project reports, the ideal conditions were still not met; [3] Shortages of initial data processing. The need for automation of the initial data process will help to reduce the volume of manual data processing activities and accelerate data availability to be ready for use by the examiner. However, in reality, it was still taken manually; and [4] auditor's understanding of the data themselves. Success with e-audit system projects would depend on how auditors enrich their understanding of the audit process. Point 1-3 are closely related to auditee IT Maturity, while point 4 is related to auditor competency.

Many studies and researches that discuss the role of information technology in accounting audits have been widely carried out, such as Dowling and Leech (2007: 92) showing that the audit support system is the application of technology used by companies as the key to successful audits to facilitate an efficient and effective audit process. This system includes electronic paperwork, extensive help files, accounting and audit standards, relevant regulations, and decision aids. 
The e-Audit system model can be applied using a typical electronic audit program and information technology tools. According to Liang (2001: 130) the rapid progress of the Internet has encouraged many modern information technologies to emerge such as object-oriented middlewares, Internet security technology, and smart agents. Computer-Assisted Audit Techniques (CAAT) can be used more effectively with information technology that emerges through a new approach to Electronic Data Processing (EDP) audits, called electronic audit (e-Audit system). Shaikh (2005) suggested the use of CAAT based on an electronic audit framework that includes most of the existing features of audit software but can be designed and disseminated independently from the EDP auditee system. Finally, Zhao et al. (2004) described how CAAT must exist to conduct ongoing audits in the electronic audit process. So that the auditor's capacity and competency are needed because the auditor is a key actor who can access the database of the party which is to be audited.

To answer the research questions above needs to formulate the research problems as follows:

1. How much influence does the auditor's competency have on the successful implementation of the e-Audit system?

2. How much influence does the use of information technology have on the successful implementation of the e-Audit system?

\section{LITERATURE REVIEW}

In conducting research, of course, there must be theories that are used as a basis in accordance with the existing concepts in setting variables and indicators.

\section{Auditor Competency}

Competencies are technical and non-technical factors such as personality and behavior, soft skills and hard skills that are owned by someone. Based on the opinions of several experts (Adedoyin \& Okere, 2017; Bailey, 2003; Barac, et al., 2016; Blunt, 2014; BPKP, 2010; Gambari, Shittu \& Taiwo, 2016; Frima \& Ghina, 2017; Chen et al., 2017; Levina et al., 2017; Khrulyova \& Sakhieva 2017; Mohammed, Joshua \& Ahmed, 2018; Omarova et al., 2018; Nyarko, Agbemava, \& Bediako, 2016; Sanghi, 2007; Spencer \& Spencer, 1993; Tuanakotta, 2011; Widaryanti, Daryanto, \& Fauzi, 2016; Zandi \& Elwahi, 2016), it was concluded that Auditor Competencies include knowledge, skill, ability, suitability of personal behavior possessed to be able to perform his / her duties with good and objective results.

Competencies can be measured through several dimensions and indicators through Practical Competency (that shows a set of tasks in an authentic context), Foundational Competency (understanding that shows the basis of practical competence where it is an action to be taken), and Reflexive Competency (that demonstrate the ability to integrate performance and work understanding which the results can show the ability to adapt to situations that change quickly and to be responsible) (Abiodun, 2014; Agbo \& Aruomoaghe, 2014; Agoes \& Ardana, 2009; Ekpung, 2014; Halim, et al., 2014; Hossain, 2018; Isola, et al., 2014; Mills, 1993; Omid, 2015; Sanghi, 2007; Weatson, 2004; Gorbunova \& Kalimullin, 2017; Masalimova et al., 2017; Thibaut et al., 2018; Youwen, 2018).

\section{The Use of Information Technology}

Information technology (IT) has changed the way in which audit data is stored, retrieved and used. This new system has caused fundamental changes in the audit movement to achieve their goals. the use of information technology in the context of this research is the use of hardware, software, and communication and network technologies, as well as the combinations formed between these technologies that are used by auditors in the framework of the audit process to produce a quality audit (Bagranof, et al., 2010; Baterman \& Snell, 2004; Meihami, et al., 2013; O'Brien, 2005; Robson, et al., 2007). In this study to measure the use of information technology was through the dimensions of quality Hardware, Application Software, and Telecommunication and Network used by the auditor in carrying out the duties and audit functions (Applegate, et al., 2009; Bagranof, et al., 2010; Obrien \& Marakas, 2010; Stair \& Reynolds, 2010).

\section{The Success of e-Audit System Implementation}

The e-Audit system is expected to send or receive notifications online regarding examination correspondence activities and create a synergy between the BPK and the entity. The e-audit system will communicate with the eAuditee system through a data communication channel. The success of e-Audit System Implementation is the process of collecting data and evaluating audit evidence using information technology through data synergy between the BPK and the auditee (Fajar, 2014; Finnegan, 2011; Olasanmi, 2013; Poernomo, 2014; Zulkarnain, 2014)

The success of the e-Audit system is measured through the efficiency and effectiveness of the examination process, Flexibility, Perceive Usefulness, and System Usage (Poernomo, 2014; Purwantoro, et al., 2015; Yulius, 2013). 


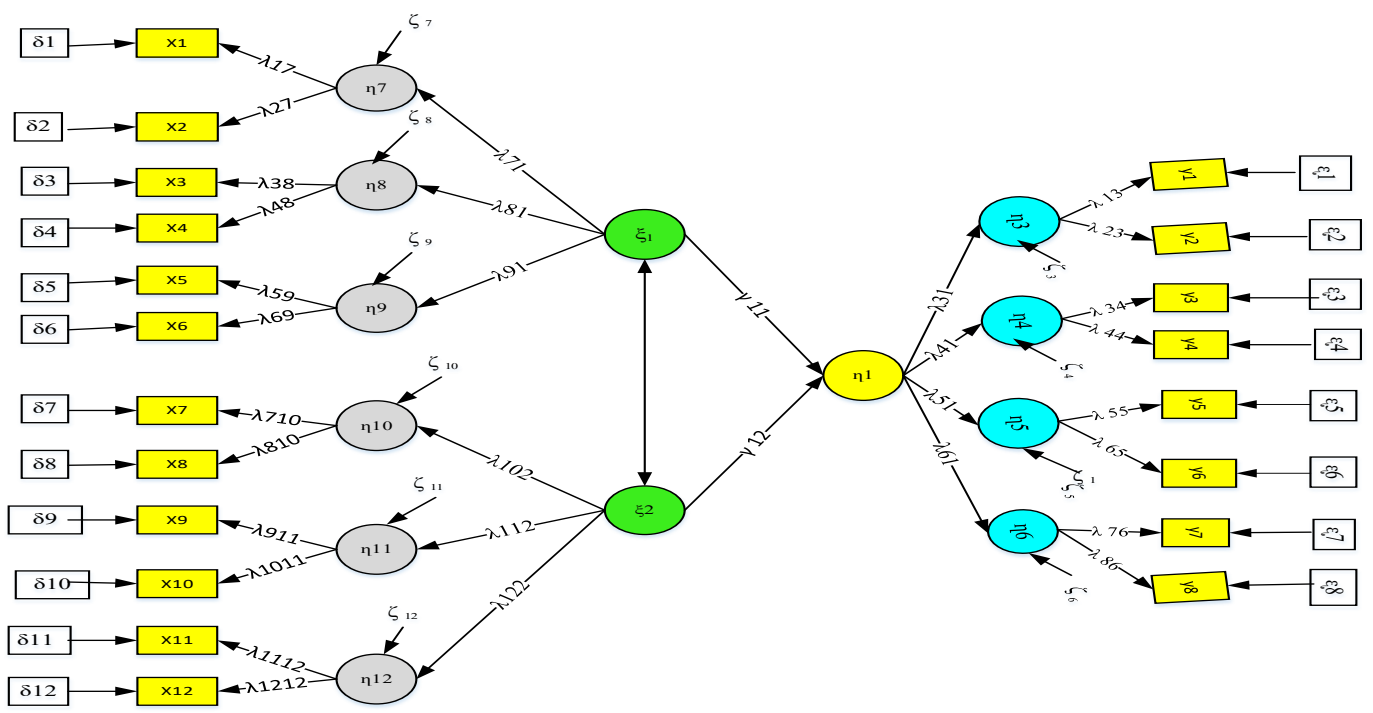

Figure 2. Research Model

Table 3. Respondents Response to Research Variables

\begin{tabular}{ccccc}
\hline No. & Variable & Total Score & Mean & Category \\
\hline $\mathbf{1}$ & Auditor Competency & 5610 & 3.65 & Good \\
\hline $\mathbf{2}$ & The Use of Information Technology & 5162 & 3.36 & Good \\
\hline $\mathbf{3}$ & The Success of e-Audit System Implementation & 6758 & 3.30 & Fair \\
\hline
\end{tabular}

Source: Data Processing Results

\section{METHODOLOGY}

Objects (Sugiyono, 2010: 2) in this study were Auditor Competency, Use of IT and Successful Implementation of e-Audit System. The research was a descriptive (Sekaran \& Bougie, 2013: 97) and verification research (causal study) (Sekaran \& Bougie, 2013: 98). In this study, variable operationalization could be done by looking at it through the dimensions of Auditor Competency, Use of IT and Successful Implementation of E-Audit System. The target population consisted of 3,500 BPK Auditors with the position of First Examiner, Young Examiner, Intermediate Examiner, and Main Examiner. This study would use a minimum sample of 380 selected by simple random sampling (Wijanto, 2015: 55). Data collection method was by distributing questionnaires, either directly visiting the analysis unit or sent via post / JNE, the instruments used were questionnaires, while the data used in this study were primary and secondary data.

The statistical descriptive analysis is the process of transforming research data into tabulation forms so that it is easily understood and interpreted. Generally, this is used to provide information about the characteristics of research variables and demographic data of respondents (Indrianto \& Supomo, 2002: 170; Hair, et al., 2014: 12; Joseph F. Healey, 2009: 16; Sekaran \& Bougie, 2010: 349; Sugiyono, 2010: 207). Verification analysis is carried out using structural equation modeling or what is called the Structural Equation Model (SEM) (Bollen, 1989; Ghozali, 2014: 3; Wijanto, 2015: 39). Path diagrams are developed as a method to study the effects directly and indirectly of the independent variable (independent/exogenous variables) on the dependent variable (dependent/endogenous variable). The theoretical model that has been constructed is then drawn into a path diagram. This research path diagram is presented in Figure 2.

\section{RESULTS AND ANALYSIS}

This study used statistical descriptive analysis and verification analysis. Descriptive statistical analysis showed the average score, standard deviation, and relative frequency of each variable. The variables in this study consist of Auditor Competency, the Use of Information Technology, and the Success of e-Audit System Implementation. Furthermore, the description of each variable can be seen in Table 3.

Based on Table 3, the variables that have the total score and average categorized as 'good' are Auditor Competence and Information Technology Use, while for Successful Implementation the e-Audit System falls within the category of 'fair'. 
Supriadi et al. / Influence of Auditor Competency in Using Information Technology ...

Table 4. Variable Auditor Competency Validity and Reliability Test

\begin{tabular}{|c|c|c|c|c|c|c|c|}
\hline Latent Variable & Indicator & $\Lambda$ & $\lambda^{2}$ & $\mathbf{E}$ & CR & VE & Note \\
\hline \multicolumn{8}{|c|}{ First Order } \\
\hline \multirow{2}{*}{ PC } & $\mathrm{X} 1$ & .653 & .426 & .574 & \multirow{2}{*}{.752} & \multirow{2}{*}{.609} & \multirow{2}{*}{ Reliable } \\
\hline & $x 2$ & .889 & .790 & .209 & & & \\
\hline \multirow{2}{*}{ FC } & $\mathrm{X3}$ & .872 & .760 & .239 & \multirow{2}{*}{.771} & \multirow{2}{*}{.630} & \multirow{2}{*}{ Reliable } \\
\hline & $\mathrm{X} 4$ & .707 & .500 & .500 & & & \\
\hline \multirow{2}{*}{$\mathrm{RC}$} & $\mathrm{X5}$ & .631 & .398 & .602 & \multirow{2}{*}{.686} & \multirow{2}{*}{.525} & \multirow{2}{*}{ Reliable } \\
\hline & $x 6$ & .808 & .653 & .348 & & & \\
\hline \multicolumn{8}{|c|}{ Second Order } \\
\hline \multirow{3}{*}{$\mathrm{KA}$} & PC & .910 & .828 & .172 & \multirow{3}{*}{.976} & \multirow{3}{*}{.933} & \multirow{3}{*}{ Reliable } \\
\hline & $\mathrm{FC}$ & .995 & .990 & .010 & & & \\
\hline & $\mathrm{RC}$ & .990 & .980 & .020 & & & \\
\hline
\end{tabular}

Source: Data Processing

Table 5. Variable Use of Information Technology Validity and Reliability Test

\begin{tabular}{|c|c|c|c|c|c|c|c|}
\hline Latent Variable & Indicator & $\Lambda$ & $\lambda^{2}$ & E & CR & VE & Note \\
\hline \multicolumn{8}{|c|}{ First Order } \\
\hline \multirow{2}{*}{ HW } & $\mathrm{X} 7$ & .728 & .530 & .469 & \multirow{2}{*}{.738} & \multirow{2}{*}{.586} & \multirow{2}{*}{ Reliable } \\
\hline & $\mathrm{X} 8$ & .801 & .642 & .359 & & & \\
\hline \multirow{2}{*}{ SW } & $\times 9$ & .871 & .759 & .242 & \multirow{2}{*}{.823} & \multirow{2}{*}{.699} & \multirow{2}{*}{ Reliable } \\
\hline & $\mathrm{X} 10$ & .800 & .640 & .360 & & & \\
\hline \multirow{2}{*}{ JT } & $\mathrm{X} 11$ & .861 & .741 & .259 & \multirow{2}{*}{.837} & \multirow{2}{*}{.720} & \multirow{2}{*}{ Reliable } \\
\hline & $\mathrm{X} 12$ & .836 & .699 & .302 & & & \\
\hline \multicolumn{8}{|c|}{ Second Order } \\
\hline \multirow{3}{*}{ PTI } & $\mathrm{HW}$ & .924 & .854 & .146 & \multirow{3}{*}{.980} & \multirow{3}{*}{.941} & \multirow{3}{*}{ Reliable } \\
\hline & SW & .995 & .990 & .010 & & & \\
\hline & $\mathrm{JT}$ & .990 & .980 & .020 & & & \\
\hline
\end{tabular}

Source: Data Processing

In the verification analysis, the authors used Lisrel software which was carried out with several stages of analysis, namely Confirmatory Factor Analysis / CFA to determine whether or not the observed variables are valid and reliable to the next stage and full SEM analysis.

Variable 'Auditor Competency' was measured in 3 dimensions consisting of 6 indicators. For more details see in Table 4.

From the first order test on the dimensions of PC, FC, and RC, all the indicators had a loading factor above 0.5, so that all indicators were valid in measuring the dimensions of PC, FC and RC. For all dimensions of Auditor Competency, CR value was 0.7 and VE value was above 0.5. This showed that the dimensions of Auditor Competency can be said to be reliable. In the second order test of variable Auditor Competency, all dimensions had a loading factor above 0.5 , so that all dimensions were valid in measuring the variable Auditor Competency.

The variable Use of Information Technology was measured in 3 dimensions consisting of 6 indicators. For more details, see in Table 5.

From the first order test on the dimensions of HW, SW and JT, all indicators had a loading factor above 0.5, so that all indicators were valid in measuring the dimensions of HW, SW and JT. For all dimensions of the Use of Information Technology, the CR value was 0.7 and the VE value was above 0.5 . This showed that the dimensions of the Use of Information Technology can be said to be reliable. In the Second Order test results on the variable Use of Information Technology, all dimensions had a loading factor above 0.5 , so that all dimensions were valid in measuring the variable Use of Information Technology.

Furthermore, the variable was measured by 34 dimensions consisting of 8 indicators. For more details, see Table 6. 
Table 6. Variable Success of the Implementation e-Audit System Validity and Reliability Test

\begin{tabular}{|c|c|c|c|c|c|c|c|}
\hline Latent Variable & Indicator & $\lambda$ & $\lambda^{2}$ & $\mathbf{E}$ & CR & VE & Note \\
\hline \multicolumn{8}{|c|}{ First Order } \\
\hline \multirow{2}{*}{$\mathrm{E} \& \mathrm{E}$} & $\mathrm{Y} 1$ & .803 & .645 & .356 & \multirow{2}{*}{.700} & \multirow{2}{*}{.541} & \multirow{2}{*}{ Reliable } \\
\hline & $\mathrm{Y} 2$ & .661 & .437 & .563 & & & \\
\hline Flex & Y3 & .000 & .000 & .000 & .000 & .000 & Reliable \\
\hline \multirow{2}{*}{ EOU } & $\mathrm{Y} 5$ & .739 & .546 & .454 & \multirow{2}{*}{.801} & \multirow{2}{*}{.671} & \multirow{2}{*}{ Reliable } \\
\hline & Y6 & .892 & .796 & .205 & & & \\
\hline \multirow{2}{*}{ SU } & $\mathrm{Y} 7$ & .850 & .723 & .277 & \multirow{2}{*}{.802} & \multirow{2}{*}{.670} & \multirow{2}{*}{ Reliable } \\
\hline & Y8 & .785 & .616 & .384 & & & \\
\hline \multicolumn{8}{|c|}{ Second Order } \\
\hline \multirow{4}{*}{ IEA } & $\mathrm{E} \& \mathrm{E}$ & .995 & .990 & .010 & \multirow{4}{*}{.963} & \multirow{4}{*}{.868} & \multirow{4}{*}{ Reliable } \\
\hline & Flex & .772 & .596 & .404 & & & \\
\hline & EOU & .994 & .988 & .012 & & & \\
\hline & SU & .947 & .897 & .103 & & & \\
\hline
\end{tabular}

Source: Data Processing

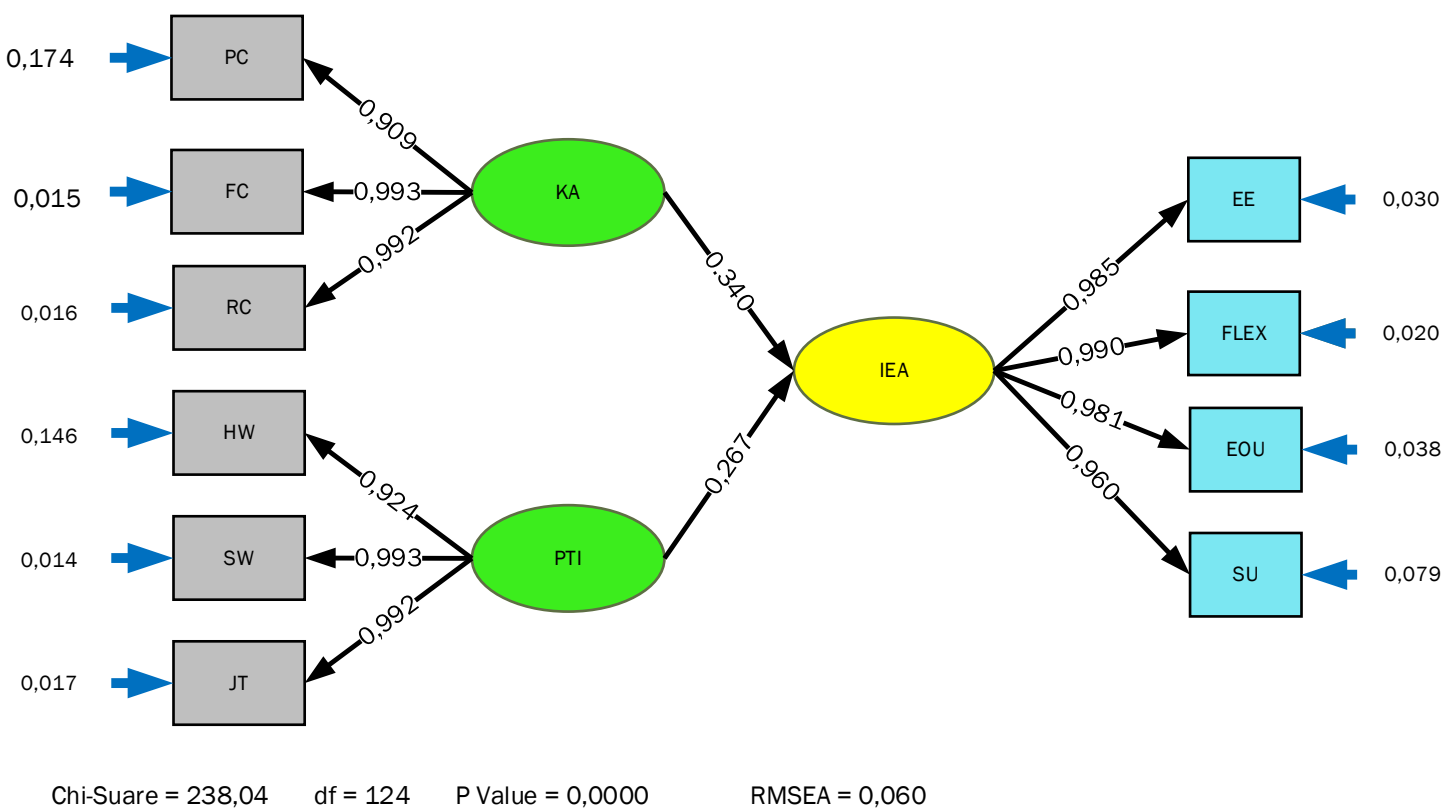

Gambar 2

Figure 3. Results of Full Structural Modeling Modification (Standardized)

First order testing on the dimensions of E \& E, Flex, EOU and SU showed that all indicators had a loading factor above 0.5 , so that all indicators were valid in measuring the dimensions of E \& E, Flex, EOU and SU. For all dimensions of the Success of the e-Audit System Implementation, the CR value was 0.7 and the VE value is above 0.5. This shows that the dimensions of Successful Implementation of e-Audit Systems can be said to be reliable. In the Second Order test results of the variable Success of the Implementation of the e-Audit System, all dimensions have a loading factor above 0.5 , so that all dimensions were valid in measuring the variables of Success of e-Audit System Implementation.

This section of Full Structural Modeling Testing Results would describe the evaluation results of the fit model and the estimated parameter values of the Structural Equation Modeling. The empirical model generated from the theoretical model in this study required full modeling testing. Analysis of the estimation of the full structural modeling illustrated the relationship between latent variables and could be done if the measurement model had been analyzed through Confirmatory Factor Analysis. Test results for structural equations were presented in the Figure 3. Full model SEM testing was carried out with two types of tests, namely the suitability of the model test and the model hypothesis test.

The results of structural equation test are presented in Figure 3. Full SEM testing was carried out with two types of tests, namely the suitability of the model test and the model hypothesis test. Full SEM testing is used to see the feasibility or suitability of the model. Evaluation of the suitability of a good structural equation modeling by comparing the recommended fit index values is presented in Table 7. 
Supriadi et al. / Influence of Auditor Competency in Using Information Technology ...

Table 7. Evaluation of Structural Modeling Fit Indexes

\begin{tabular}{ccccc}
\hline No & Goodness of Fit & Target Value & Value & Description \\
\hline 1 & Chi-square (P-value) & $\mathrm{p}$-value $\geq .05$ & 238.041 & - \\
\hline 2 & $\mathrm{RMSEA}$ & $\mathrm{RMSEA} \leq .08$ & .060 & Good fit \\
\hline 3 & $\mathrm{NFI}$ & $\mathrm{NFI} \geq .90$ & .987 & Good fit \\
\hline 4 & $\mathrm{NNFI}$ & $\mathrm{NNFI} \geq .90$ & .992 & Good fit \\
\hline 5 & $\mathrm{CFI}$ & $\mathrm{CFI} \geq .90$ & .993 & Good fit \\
\hline 6 & $\mathrm{IFI}$ & $\mathrm{FII} \geq .90$ & .993 & Good fit \\
\hline 7 & $\mathrm{RFI} \geq .90$ & .984 & Good fit \\
\hline 8 & $\mathrm{RFI}$ & $\mathrm{SRMR} \leq .05$ & .026 & Good fit \\
\hline 9 & $\mathrm{SRR}$ & $\mathrm{GFI} \geq .90$ & .905 & Good fit \\
\hline 10 & $\mathrm{GFI}$ & $\mathrm{AGFI} \geq .90$ & .869 & Marginal fit \\
\hline
\end{tabular}

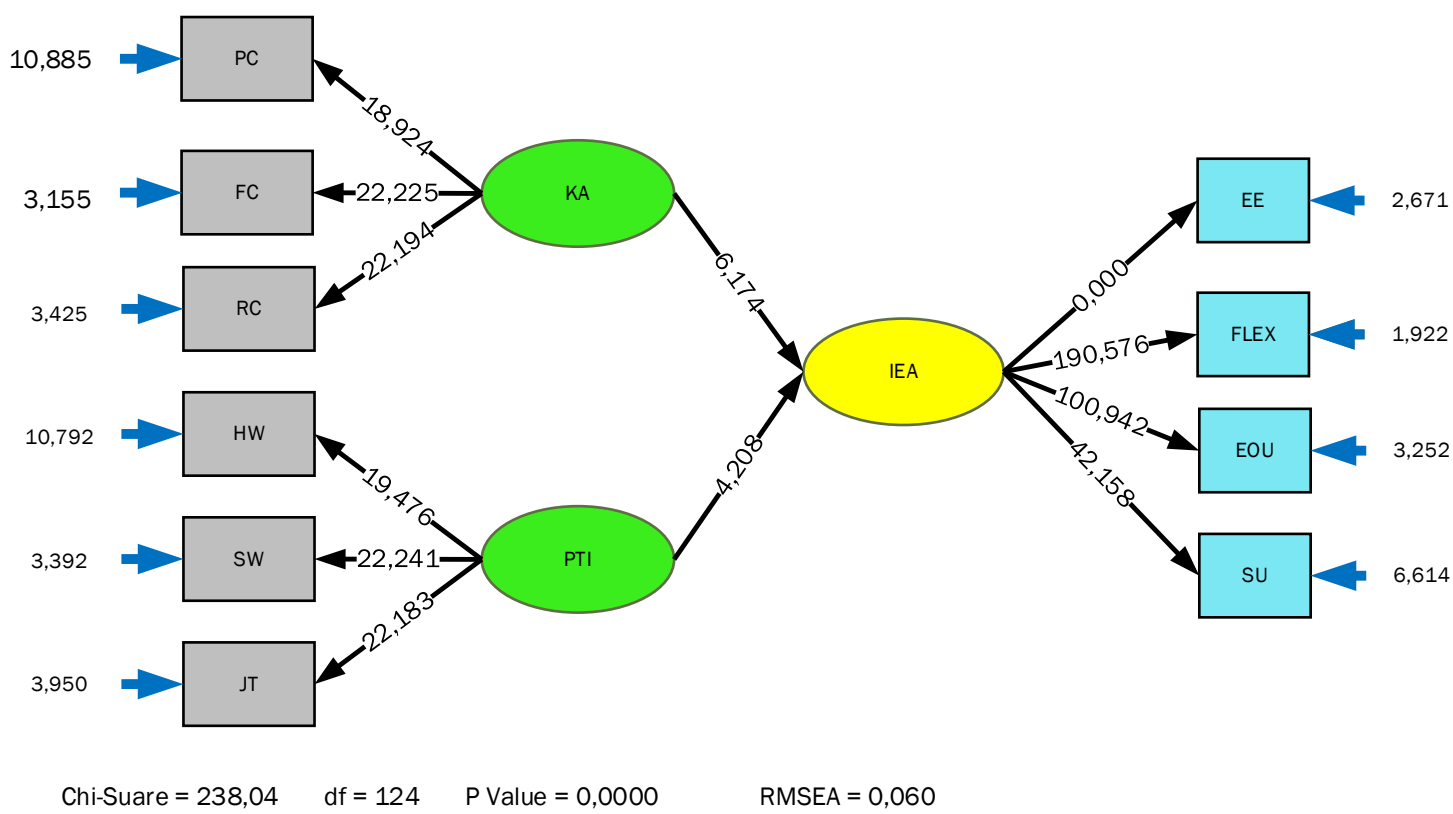

Figure 4. Results of Full Structural Modeling Modification (T values)

Table 8. Summary of estimation results of the Path Coefficient and Statistical Test

\begin{tabular}{ccccc}
\hline Relation & Path & T-value & R-square (Parsial) & R-square (Simultan) \\
\cline { 1 - 4 } $\mathrm{KA} \rightarrow \mathrm{IEA}$ & .340 & .174 & .249 & \multirow{2}{*}{0,447} \\
\hline $\mathrm{PTI} \rightarrow \mathrm{IEA}$ & .267 & .208 & .198 & \\
\hline
\end{tabular}

Based on Table 7, it can be seen that the results of overall model suitability testing based on RMSEA of 0.060 were fit, as well as almost all other GOF indexes had met the fit criteria, so that they could be continued to the next analysis stage. After testing the suitability of the model, then the research hypotheses were tested through a structural modeling.

Table 8 shows a summary of the results of estimating the structural modeling of the relationship between latent variables through the path coefficient test.

Through the recapitulation results contained in Table 8, it can be seen that the variable Auditor Competency (KA), the Use of Information Technology (PTI) has an effect of $44.7 \%$ on the Success of the e-Audit System Implementation (IEA), while the remaining $55.3 \%$ is influenced by other variables besides the 2 independent variables. Judging from the path coefficient values, the most dominant variables, respectively, to influence the Success of the e-Audit System Implementation (IEA) were Auditor Competency (KA) and Use of Information Technology (PTI) with path values of $0.340(56 \%)$ and $0.267(44 \%)$, respectively. 
Table 9. Results of Testing the Influence of Auditor Competency on the Success of the e-Audit System Implementation

\begin{tabular}{ccc}
\hline Path Coeff. & $\mathbf{T}_{\text {count }}$ & H1 \\
\hline .340 & .174 & acceptable
\end{tabular}

Table 10. Results of Testing the Influence of the Use of Information Technology on the Success of the e-Audit System Implementation

\begin{tabular}{ccc}
\hline Path Coeff. & Tcount $_{\text {H2 }}$ \\
\hline 0.267 & 4.208 & Acceptable \\
\hline
\end{tabular}

\section{HYPOTHESES TEST}

\section{Influence of Competence Auditor (KA) to the Success of e-Audit System Implementation (IEA)}

The first hypothesis that will be tested is 'Auditor Competency influences the Success of the e-Audit System Implementation'. In the table of the path coefficient calculation, it can be seen that the path coefficient between Auditor Competency (KA) and the Success of the e-Audit System Implementation (IEA) was 0.340 with a positive direction. That is, the higher or better the Auditor Competency (KA), the more successful the e-audit system implementation (IEA). Furthermore, the path coefficients were tested to prove whether there was a significant effect of the variable Auditor Competency (KA) on the Success of the e-Audit System Implementation (IEA).

The following is presenting the results of the significance test of the hypotheses through the statistical hypotheses as follows:

$\mathrm{H}_{0}$ : Auditor Competency does not influence the Success of the e-Audit System Implementation

$\mathrm{H}_{1}$ : Auditor Competency influences the Success of the e-Audit System Implementation

Based on Table 9, it can be seen that the $t_{\text {count }}$ of the variable Auditor Competency (KA) is 6.174 which is greater than $t_{\text {table }}(1.96)$. Because the $t_{\text {count }}$ value (6.174) is greater than the $t_{\text {table }}(1.96)$, then at the $5 \%$ error rate it is decided to accept $\mathrm{H} 1$ and reject H0, so the first hypothesis is accepted. So, based on the test results, it can be concluded that there is a significant influence of Auditor Competence on the Success of the e-Audit System Implementation.

The results of this study provided empirical evidence that Auditor Competency has a significant positive influence on the Success of the e-Audit System Implementation. That is, the higher the Auditor Competency the more the Success of the e-Audit System Implementation.

\section{The Influence of the Use of Information Technology (PTA) on the Success of the e-Audit System Implementation}

The second hypothesis is 'the Use of Information Technology influences the Success of the e-Audit System Implementation'. In the table of the path coefficient calculation, it can be seen that the path coefficient between the Use of Information Technology (PTI) and the Success of the e-Audit System Implementation (IEA) was 0.267 with a positive direction. That is, the higher or better the use of Information Technology (PTI), the more successful the e-Audit System Implementation (IEA). Furthermore, the path coefficients were tested to prove the presence or absence of a significant influence of the variable Use of Information Technology (PTI) on the Success of the e-Audit System Implementation (IEA).

The following is presenting the results of the significance test of the hypotheses through the statistical hypotheses as follows

$\mathrm{H}_{0}$ : The Use of Information Technology does not influence the Success of the e-Audit System Implementation

$\mathrm{H}_{2}$ : The Use of Information Technology influences the Success of the e-Audit System Implementation

Based on Table 10, it can be seen that the $t_{\text {count }}$ of the variable the Use of Information Technology (PTI) is 4.208 which is greater than $t_{\text {table }}(1.96)$. Because the $t_{\text {count }}$ value (4.208) is greater than the $t_{\text {table }}(1.96)$, then at the $5 \%$ error rate it is decided to accept $\mathrm{H} 2$ and reject $\mathrm{H} 0$, so the second hypothesis is accepted. So, based on the test results, it can be concluded that there is a significant influence of the Use of Information Technology on the Success of the eAudit System Implementation.

The results of this study provided empirical evidence that the Use of Information Technology has a significant positive influence on the Success of the e-Audit System Implementation. That is, the higher the Use of Information Technology the more the Success of the e-Audit System Implementation. 


\section{CONCLUSION}

The findings based on the evaluation of Structural Model Fit Indexes resulted in overall model suitability testing based on RMSEA of 0.060 as fit, as well as almost all other GOF indexes meeting the fit criteria. Through the recapitulation results contained in this study, it can be seen that the variable Auditor Competency (KA) and the use of Information Technology (PTA) have a positive effect of $44.7 \%$ on the Success of the e-Audit System Implementation (IEA), while the remaining $55.3 \%$ is influenced by other variables besides the two independent variables. Judging from the path coefficient values, the most dominant variables, respectively, to influence the Success of the e-Audit System Implementation (IEA) were Auditor Competency (KA) and Use of Information Technology (PTI) with path values of $0.340(56 \%)$ and $0.267(44 \%)$, respectively.

Based on testing the hypotheses, the results of this study provided empirical evidence that Auditor Competence has a significant positive influence on the Success of the e-Audit System Implementation. That is, the higher the Auditor Competency the more the Success of the e-Audit System Implementation. Likewise, the Use of Information Technology has a significant positive influence on the success of the e-Audit System Implementation. That is, the higher the Use of Information Technology the more the Success of the e-Audit System Implementation.

\section{REFERENCES}

Abiodun, B. Y. (2014). The Prospects of Accounting and Economic Systems in the Era of Global Knowledge Economy. The Economics and Finance Letters, 1(2), 9-14. https:/ / doi.org/10.18488/journal.29/2014.1.2/29.2.9.14

Adedoyin, O., \& Okere, E. (2017). The Significance of Inclusion Concept in the Educational System as Perceived by Junior Secondary School Teachers: Implications for Teacher Training Programmes in Botswana. Global Journal of Social Sciences Studies, 3(1), 13-28. https:/ / doi.org/10.20448/807.3.1.13.28

Agbo, S., \& Aruomoaghe, J. A. (2014). Performance Audit: A Tool for Fighting Corruption in the Nigeria's Public Sector Administration. International Journal of Management and Sustainability, 3(6), 374-383.

Agoes, S. (2012). Auditing: Petunjuk Praktis Pemeriksaan Akuntan oleh Akuntan Publik, buku satu, edisi keempat. Jakarta: Salemba Empat.

Agoes, S., \& Ardana, C. (2009). Etika Bisnis dan Profesi. Jakarta: Salemba Empat.

Applegate, L. M., et al. (2009). Corporate Information Strategy and Management. New York: Mc Graw-Hill.

Bagranoff, N. A., et al. (2010). Core Concept of Accounting Information Systems. U.S.A.: John Wiley \& Sons, Inc.

Bailey, A. D. (2003). Research Opportunities in Internal Auditing. pp. 74-96. Florida: The Institute of Internal Auditor Research Foundation.

Barac, K, et al. (2016). The Capability and Competency Requirements of Auditors in Today's Complex Global Business Environment. London: ICAS.

Baterman, T. S., \& Snell, S. A. (2004). Management: The New Competitive Landscape (6 $6^{\text {th }}$ Ed.). New York: McGraw Hill.

Blunt, A., et al. (2014). Human Resources Professional Competency Framework. Human Resources Professionals Association (HRPA).

Bollen, K. A. (1989). Structural Equation with Laten VARIABELS. John Wiley \& Sons. https:/ / doi.org/10.1002/9781118619179

BPK. (2011a). Laporan Implementasi e-Audit (e-Audit Implementation Report), pp. 1-46. Jakarta: Badan Pemeriksa Keuangan Republik Indonesia

BPK. (2014). Peer Review Report on the Supreme Audit Board of the Republic of Indonesia by NIK (BPK Polandia). pp. 2526. Jakarta: Badan Pemeriksa Keuangan Republik Indonesia.

BPK. (2017). Sinergi Brsama Membrangun e-Audit. pp. 89-92. Jakarta: Badan Pemeriksa Keuangan Republik Indonesia.

Cahyono, T. T., \& Siswantoro, D. (2016). Analisis Kelayakan E-Audit Untuk Pemeriksaan Keuangan Negara Pada Badan Pemeriksa Keuangan Republik Indonesia. Simposium Nasional Akuntansi XIX, Lampung 2016.

Chen F., Gorbunova N. V., Masalimova A. R., \& Bírová J. (2017). Formation of ICT-Competence of Future University School Teachers. EURASIA Journal of Mathematics, Science and Technology Education, 13(8), 4765-4777. https:/ / doi.org/10.12973/eurasia.2017.00963a

Dowling, C., \& Leech, S. (2007). Audit support systems and decision aids: Current practice and opportunities for future research. International Journal of Accounting Information Systems8 (2007), pp. 92-116. https:/ / doi.org/10.1016/j.accinf.2007.04.001 
Ekpung, E. G. (2014). Public infrastructure spending and economic growth in Nigeria: An Error Correction Mechanism (ECM) approach. Journal of Social Economics Research, 1(7), 129-140.

Fajar, I. M. (2014). E-Audit and Its Impact on Audit Quality in BPK RI. The Hague University of Applied Sciences.

Finnegan, A. (2011). Revenue Audit and e-Audit Techniques. Irish Tax Institute. pp. 74-76.

Frima, M. Y., \& Ghina, A. (2017). The Analysis of Entrepreneurship Program within Higher Education (Institution Case Study of the Management of Business in Telecommunications and Informatics, Telkom UniversityIndonesia). International Journal of Education and Practice, 5(10), 155-170. https:/ / doi.org/10.18488/journal.61.2017.510.155.170

Gambari, A. I., Shittu A. T., \& Taiwo, O. A. (2016). Enhancing Students' Understanding of Algebra Concepts through Cooperative Computer Instruction. Pedagogical Research, 1(2), 55. https:/ / doi.org/10.20897/lectito.201655

Ghozali, I. (2014). Structural Equation Modeling: Teori, Konsep dan Aplikasi dengan Program Lisrel 9.0. (Edisi 4). Penerbit Universitas Diponegoro.

Gorbunova, N. V., \& Kalimullin, A. M. (2017). Simulation of the Process of Training the Future Primary School Teachers for Organizing Extracurricular Activities. Elementary Education Online, 16(4), 1860-1872.

Halim, A., et al. (2014). Effect of Competence and Auditor Independence on Audit Quality with Audit Time Budget and Professional Commitment as a Moderation Variable. International Journal of Business and Management Invention. 3, 64-74.

Healey, J. F. (2009). Statistics: A Tool for Social Research (8th Ed).

Hossain, M. M. (2018). Implementing Social Justice in Teaching and Learning English at University Level in Bangladesh: Necessities, Approaches and Challenges. International Journal of English Language and Literature Studies, 7(1), 7-14. https:/ / doi.org/10.18488/journal.23.2018.71.7.14

Indrianto. N., \& Supomo. B. (2002). Metode Penelitian Bisnis untuk Akuntansi dan Manajemen (Edisi pertama). Yogyakarta: BPFE.

Isola, L. A., Taiwo, O. E., Victor, A., \& Leke, B. K. (2014). An Enquiry into the Contributions of Microfinance Institutions towards the Development of Small Scale Business in Nigeria. International Journal of Business, Economics and Management, 1(6), 88-100.

Khrulyova, A. A., \& Sakhieva R. G. (2017). Forming of Informational Culture as a Necessary Condition of the Level Raising of Higher Education. Man In India, 97(15), 211-225.

KPK. (2017). Agus Rahardjo Ketua KPK dalam seminar yang diselenggarakan IPDN. Peran KPK bagi Peningkatan Layanan Publik di Bidang Pendidikan, Kesehatan, Stabilitas Harga Pokok dan Penegakan Hukum di Daerah, Pontianak, 4 April 2017.

Levina, E. Y., Masalimova, A. R., Kryukova, N. I., Grebennikov, V. V., Marchuk, N. N., Shirev, D. A., Renglikh, K. A., \& Shagieva, R. V. (2017). Structure and Content of e-Learning Information Environment Based on GeoInformation Technologies. EURASIA Journal of Mathematics, Science and Technology Education, 13(8), 50195031.

Liang, D., Lin, F., \& Wu S. (2001). Electronically auditing edp systems with the support of emerging information technologies. International Journal of Accounting Information Systems, 2(June), 130-147. https:// doi.org/10.1016/S1467-0895(01)00014-8

Lubis, M. A., Wekke, I. S., Yunus, M. M., \& Nordin, N. M. (2009). Multicultural Approach and Information Communication Technology In Arabic Language Teaching: Research on Indonesian Pesantren. In 3rd WSEAS International Conference on Energy Planning, Energy Saving, Environmental Education. 3rd WSEAS RES 2009. WSEAS WWAI 2009 (pp. 127-135).

Masalimova, A. R., Levina, E. Y., Platonova, R. I., Yakubenko, K. Yu., Mamitova, N. V., Arzumanova, L. L., Grebennikov, V. V., \& Marchuk, N. N. (2017). Cognitive Simulation as Integrated Innovative Technology in Teaching of Social and Humanitarian Disciplines. EURASIA Journal of Mathematics, Science and Technology Education, 13(8), 4915-4928. https:/ / doi.org/10.12973/eurasia.2017.00973a

Meihami, B., et al. (2013). The Role \& Effect of Information Technology and Communications on Performance of Independent Auditors (evidences of audit institutions in Iran). Interdisciplinary Journal of Contemporary Research in Business, 4(12), 829-849.

Mills, D. (1993). Quality Auditing (1st Ed.). London, UK: Capman and Hall. https://doi.org/10.1007/978-94-0110697-9 
Moermahadi. (2017). Moermahadi Ketua BPK dalam acara penyerahan LKPP Audited kepada Presiden Republik Indonesia di Istana Bogor, Jumat. Retrieved on 26 May 2017 from https://m.tempo.co/read/news/2017/ 05/26/087878896/bpk-dan-pemerintah-terapkan-e-audit-untuk-lkpp-2017

Mohammed, A. M., Joshua, O., \& Ahmed, M. N. (2018). Audit Fees and Audit Quality: A Study of Listed Companies in the Downstream Sector of Nigerian Petroleum Industry. Humanities and Social Sciences Letters, 6(2), 59-73. https:/ / doi.org/10.18488/journal.73.2018.62.59.73

Nyarko, I. K., Agbemava, E., \& Bediako, A. K. (2016). Effectiveness and Usefulness of Personal Tax Reliefs: A Study of Ghana Revenue Authority's Domestic Tax Division. Asian Journal of Economics and Empirical Research, 3(1), 59-70. https:/ / doi.org/10.20448/journal.501/2016.3.1/501.1.59.70

O’Brien, J. A. 2005. Pengantar Sistem Informasi, Perspektif Bisnis dan Manajerial (Edisi 12). Terjemahan: Introduction to Information Systems (12 ${ }^{\text {th }}$ Ed.), Palupi W. (editor), Dewi F. dan Deny A. K. (penerjemah). Penerbit Salemba Empat, Jakarta.

O’Brien, J. A., \& Marakas, G. M. (2010). Management Information Systems (8th Ed.). New York: McGraw-Hill/Irwin.

Olasanmi, O. O. (2013). Computer Aided Audit Techniques and Fraud Detection. Research Journal of Finance and Accounting, 4(5).

Omarova, L. B., Kalimullin, A. M., Grudtsina, L. Y., Korzhuev, A. V., \& Zhukova, M. Y. (2018). Philosophical anthropology in postmodernism. XLinguae, 11(3), 76-85.

Omid, A. M. (2015). Qualified audit opinion, accounting earnings management and real earnings management: Evidence from Iran. Asian Economic and Financial Review, 5(1), 46-57. https:/ / doi.org/10.18488/journal.aefr/2015.5.1/102.1.46.57

Poernomo, H. (2011). E-Audit Untuk Rakyat: Menciptakan Efisiensi dan Efektivitas Pemerikasaan BPK. Penerbit: BPK RI.

Praseno, A. (2012). IT-Based Audit (e-Audit) Plan in Indonesia: An Analysis of the Program Logic, Feasibility, and Alternatives. International Institute of Social Studies, The Hague, The Netherlands (Tidakdipublikasikan).

Republik Indonesia. (2012). Peraturan Badan Pengawasan Keuangan dan Pembangunan (BPKP) tentang Standar Kompetensi Auditor, BPKP. PER-211/K/JF/2010.

Robson, K., et al. (2007). Transforming Audit Technologies Business risk Audit methodologies and the Audit field. Journal of accounting, organization and society, 32, 409-438.

Sanghi, S. (2007). The Handbook of Competency Mapping Understanding, Designing and Implementing Competency Models in Organizations (2nd Ed.). Thousand Oaks, CA: Sage Publications Inc.

Sekaran, U., \& Bougie, R. (2010). Research methods for business: A skill building approach (5th Ed.). West Sussex, UK: John Wiley \& Sons Ltd.

Shaikh, J. M. (2005). E-commerce impact: Emerging technology - electronic auditing. Managerial Auditing Journal 20(4), 408-421. https:// doi.org/10.1108/02686900510592089

Spencer, L., \& Spencer, S. M. (1993). Competence at Work, Models For Superior Performance. Canada: John Wiley \& Sons, Inc.

Stair, M. R., \& Reynolds, G. W. (2010). Principles of Information Systems: A Managerial Approach. (9th Ed.). Australia: Thomson Course Technology.

Sugiyono. (2010). Metode Penelitian Pendidikan Pendekatan Kuantitatif, kualitatif, dan RED. Bandung: Alfabeta.

Thibaut, L., Ceuppens, S., De Loof, H., De Meester, J., Goovaerts, L., Struyf, A., ..., Depaepe, F. (2018). Integrated STEM Education: A Systematic Review ofInstructional Practices in Secondary Education. European Journal of STEM Education, 3(1), 02. https://doi.org/10.20897/ejsteme/85525

Tuanakotta, T. M. (2011). Berpikir Kritis dalam Auditoring. Jakarta: Penerbit Salemba Empat.

Weatson, H. (2004). Skills Audit. The Skills Framework.

Wekke, I. S., \& Hamid, S. (2013). Technology on language teaching and learning: a research on Indonesian pesantren. Procedia-Social and Behavioral Sciences, 83, 585-589. https:/ / doi.org/10.1016/j.sbspro.2013.06.111

Widaryanti, W., Daryanto, A., \& Fauzi, A. M. (2016). The Students Satisfaction Oriented: Academic Service Improvement Strategy, Department of Aquatic Resources Management, Bogor Agricultural University, Indonesia. Journal of Education and e-Learning Research, 3(3), 98-105.

Wijanto, S. H. (2015). Metode Penelitian Menggunakan Structural Equation Modelling dengan Lisrel 9. Lembaga Penerbit Fakultas Ekonomi Universitas Indonesia.

Youwen, Z. (2018). The Critical Discourse Analysis of Language Teacher's Instructional Decisions. International Journal of Educational Technology and Learning, 2(2), 59-64. https:/ / doi.org/10.20448/2003.22.59.64 
Zandi, G., \& Elwahi, A. S. M. (2016). Tax Compliance Audit: The Perspectives of Tax Auditors in Malaysia. Asian Development Policy Review, 4(4), 143-149. https:/ / doi.org/10.18488/journal.107/2016.4.4/107.4.143.149

Zhao, N., Yen, D. C., \& Chang, I. (2004). Auditing in the e-commerce era. Information Management E Computer Security, 12(5), 389-400. https:/ / doi.org/10.1108/09685220410563360

Zulkarnain, P. D. (2014). IntOGo: Inter-government open government model. 2014 International Conference on ICT for Smart Society (ICISS), Bandung, 2014, pp. 139-144.

\section{http://www.ejmste.com}

